\title{
POPULASI ORONG-ORONG (Gryllotalpa spp.) DAN KERUSAKAN TANAMAN PADI MUSIM TANAM GADU DI PUNGGUR, LAMPUNG TENGAH
}

\section{POPULATION OF MOLE CRICKET (Gryllotalpa spp.) AND RICE DAMAGE ON GADU PLANTING SEASON IN PUNGGUR, LAMPUNG TENGAH}

\author{
Solikhin dan Purnomo* \\ Jurusan Proteksi Tanaman, Fakultas Pertanian Unila \\ Jl. Sumantri Brojonegoro No. 1 Bandar Lampung \\ *Email:purjomo@yahoo.com
}

\begin{abstract}
Rice are the crop favored by many pest from beginning of growth until harvest. Mole cricket is a pest commonly found in the early vegetative phase. This study aims to determine population of mole cricket and the level of attack on rice in 2014 Gadu planting season in Punggur Lampung Tengah. A survey study was conducted by observing the mole cricket population and their damage since the rice was planted until the time of harvest. The resulThe results showed that the population of mole cricket is highly found in 1-5 weeks after planting. In the weeks that followed until rice harvested, the mole crikcet population decreased not be found before the harvest. Like the mole crikcet populations, the rice damage is due to an mole cricket attack only found until the 5th and 6th week after planting, and no damage after the 11th week.
\end{abstract}

Keywords: Gadu planting season, Gryllotalpa spp., mole cricket, rice.

\begin{abstract}
ABSTRAK
Tanaman padi, sejak awal pertumbuhan hingga panen, merupakan tanaman yang disukai oleh banyak hama. Orong-orong adalah hama yang biasa dijumpai pada fase awal pertumbuhan vegetatif tanaman padi. Penelitian ini bertujuan untuk mengetahui populasi orong-orong dan tingkat serangan pada tanaman padi musim tanam gadu 2014 di Punggur Lampung Tengah. Penelitian berupa survei dilakukan dengan mengamati populasi orong-orong dan kerusakan yang ditimbulkannya sejak tanaman padi ditanam di sawah hingga menjelang masa panen. Hasil penelitian menunjukkan bahwa populasi orong-orong yang cukup tinggi hanya dijumpai pada padi umur 1-5 minggu setelah tanam (mst). Pada minggu-minggu selanjutnya hingga tanaman padi dipanen, populasi orongorong menurun drastis hingga tidak dapat ditemukan lagi menjelang panen. Seperti halnya populasi orongorong, kerusakan tanaman padi yang agak tinggi akibat serangan orong-orong hanya ditemukan hingga minggu ke-5 dan ke-6 mst saja, dan tiada kerusakan setelah memasuki minggu ke-11.
\end{abstract}

Kata kunci: Gryllotalpa spp., musim gadu, orong-orong, padi. 


\section{PENDAHULUAN}

Indonesia adalah salah satu negara yang sebagian besar penduduknya menggunakan beras sebagai bahan makanan pokok. Kebutuhan beras yang setiap tahun meningkat seiring dengan peningkatan populasi penduduknya, menjadikan Indonesia tidak mudah untuk mencapai swasembada beras seperti pada tahun 1984 lalu. Melalui berbagai upaya, pemerintah Republik Indonesia selalu berusaha meningkatkan produksi gabah atau berasnya. Program Upaya Khusus (Upsus) peningkatan produksi padi, jagung, dan kedelai (Pajale) tampaknya mulai membuahkan hasil setelah diluncurkan pada awal 2015. Setelah adanya Upsus Pajale berlangsung setahun, produksi padi selama Tiga puluh tahun yang lalu, tepatnya pada tahun 1984 Indonesia pernah mencapai swasembada beras dengan produksi mencapai 25,9 juta ton, tetapi sayang swasembada tersebut tidak mampu bertahan lama. Terbukti sepuluh tahun kemudian kebutuhan beras semakin tak tercukupi meskipun produksi naik menjadi 31,1 juta ton karena jumlah penduduk meningkat menjadi 205 jutajiwa. Hal ini mengakibatkan Indonesia mengimpor beras lebih dari 3 juta ton pada tahun 1995 (Sumodiningrat, 2001), bahkan pemerintah melalui Kementerian Pertanian memenrintahkan Perum Bulog untuk mengimpor beras 500.000 ton untuk mengamankan stok beras sampai akhir tahun 2015 (Lampung Post, 2014).

Menutut Oka (1995), kendala yang dihadapi dalam peningkatan pangan khususnya padi (beras) terdiri dari dua faktor, yaitu fisik berupa bencana alam dan faktor sosial budaya berupa kekurangan modal dan rendahnya sumberdaya manusia serta faktor biologi berupa organisme pengganggu tanaman(OPT). Faktor fisik, dalam hal ini banjir, di beberapa daerah hapir tidak mungkin dihindari, sedangkan kekeringan masih dapat disiasati dengan pompa air dan pengairan secara terputus-putus inter mitten.

OPT dari golongan hama yang penting pada pertanaman padi di Indonesia antara lain adalah tikus, walang sangit, wereng coklat, dan penggerek batang padi (Singleton \& Petch, 1994). Namun sekitar duapuluh tahun terakhir muncul OPT yang penting, yaitu keong emas dan orong-orong atau biasa disebut dengan anjing tanah. Kedua hama ini mengganggu tanaman padi dari saat tanam (pindah tanam) sampai umur sekitar 30 hari setelah tanam (hst). Menurut Vergara (1990), pertanaman padi pada periode tersebut tergolong dalam fase vegetatif awal. Pada musim kemarau tahun 2013 hama ini banyak dilaporkan menyerang pertanaman padi di sentra-sentra pertanaman padi di Indonesia, salah satu diantaranya adalah yang menyerang pertanaman padi di di Madiun, Jawa Timur mencapai areal seluas 35 ha (Antarajatim.com, 2013).

Perbedaan penyebab aktivitas menyerang antara keong emas dengan orong-orong adalah keberadaan air. Keong emas menyerang saat lahan (petakan) sawah ada air yang menggenang atau mengalir, sedangkan orong-orong sebaliknya yaitu menyerang tanamn padi pada saat lahan tidak tergenang air (Galagher, 1991 atau dalam kondisi tanah lembab (Borror \& White, 1970; Solikhin, 2004).

Orong-orong tidak menyebabkan kerugian 
yang berarti jika tanaman padi berumur lebih dari 30 hst karena orong-orong tidak mampu merusak perakaran padi yang sudah cukup kuat, apalagi pada saat tersebut pertanaman padi sudah mulai sering digenangi. Lebih lanjut Vergara (1990) menyebutkan bahwa orong-orong penting pada pesemaian yang kering atau dapog atau pesemaian yang kurang mendapat pengairan.

Keberadaan orong-orong sangat dipengaruhi oleh kandungan bahan organik di dalam tanah karena bahan organik tersebut bisa menjadi makanan orongorong selain akar tanaman (rerumputan) bahkan binatang-binatang yang berukuran kecil yang berada di dalam tanah. Selain itu, keberadaan orong-orong juga sangat dipengaruhi oleh kandungan (keberadaan) air di dalam tanah (Solikhin, 2004). Penelitian ini bertujuan untuk mengetahui populasi orong-orong dan kerusakan yang diakibatkannya pada pertanaman padi di areal persawahan selama musim tanam gadu.

\section{BAHAN DAN METODE}

Pengamatan dilakukan terhadap orong orong yang ada di 8 lajur (buah) pematang masing-masing sepanjang $50 \mathrm{~m}$ pada sawah seluas 0,5 ha meliputi semua orong-orong dewasa dan pradewasa, mulai tanaman berumur 1 minggu setelah tanam (mst) sampai menjelang panen setiap minggu. Orong-orong ditangkap dengan cara menggali dan dihitung jumlahnya secara berhati-hati dari pematang seluas $1 \mathrm{~m}^{2}$ sampai kedalaman $20 \mathrm{~cm}$. Karena lebar pematang rata-rata $0,5 \mathrm{~m}^{2}$ sehingga dibutuhkan panjang pematang $2 \mathrm{~m}$ agar luas saetiap satuan percobaan mencapai luas $1 \mathrm{~m}^{2}$.
Setiap lajur (pematang) diambil contohnya sebanyak 2 tempat yang ditentukan secara acak sehingga ada 16 lokasi sampel setiap minggu. Tempat yang sudah pernah diambil sampelnya tidak diambil (digali) lagi sehingga harus menentukan tempat yang baru di dalam pematang itu.

Semua orong-orong yang tertangkap dimasukkan kedalam botol beralkohol (80\%) secara terpisah. Pengamatan juga dilakukan terhadap tanaman padi pada awal pertanaman sampai panen untuk melihat tingkat kerusakan tanaman padi yang terserang orongorong. Pengamatan ini dilakukan di daerah pinggir petakan dekat tempat pengambilan sampel orongorong pada areal seluas $1 \mathrm{~m} 2$ dengan mengambil 10 rumpun sebagai sampel untuk dicari persentase (intensitas) seranagan. Dengan jarak tanam 20 × 20 $\mathrm{cm}$ maka di dalam areal seluas $1 \mathrm{~m}^{2}$ terdapat 20 rumpun.

Data populasi (padat populasi) orong-orong yang diperoleh kemudian diolah secara deskriptif dengan menggunakan grafik dan dicari kemungkinan bentuk hubungannya dengan tingkat kerusakan tanaman padi pada musim gadu.

\section{HASIL DAN PEMBAHASAN}

Orong-orong mulai menyerang pertanaman padi segera setelah tanaman padi ditanam yaitu pada umur nol (0) hari setelah tanam (hst). Serangan orongorong terhadap tanaman padi pada akar dan dilakukan pada malam hari karena orong-orong termasuk hama nokturnal. Untuk lebih jelasnya perkembangan populasi orong-orong digambarkan oleh padat populasi yang 
tersaji dalam Gambar 1.

Orong-orong adalah hama yang dapat merusak tanaman pada berbagai fase tumbuh (Setiawati et al., 2015). Pada pertanaman padi populasi orong-orong tinggi pada saat awal tanam sampai dengan pertanaman berumur 5 minggu setelah tanam (mst), kemudian menurun secara drastis sampai menjelang panen. Tingginya populasi pada saat awal tanam ini adalah hal yang wajar karena pada saat pengolahan tanah tahap pertama sampai persiapan akhir memang sering didapati orong-orong. Orong-orong tersebut berenang pada saat tanah diolah (dibajak) karena menyelamatkan diri ke pematang atau tempat yang tidak tergenang air. Hal ini menunjukkan bahwa pada saat tidak ada pertanaman padi sebenarnya orong-orong tetap ada di areal persawahan. Sebenarnya orongorong bisa didapatkan hampir di mana saja asalkan tempat tersebut cocok, yaitu tempat yang banyak bahan organik, lembab, dan tanahnya tidak tergenang serta banyak makanan. Populasi (padat populasi) orong- orong pada pertanaman yang berumur sampai sekitar 35 hst tinggi karena petakan sawah sering berada dalam keadaan kering atau tidak tergenangi air. Kondisi ini sangat cocok bagi kehidupan orong-orong (Kalshoven, 1981).

Kondisi kering atau air tidak dalam keadaan tergenang yang merupakan kondisi yang disenangi orong-orong bisa disebabkan oleh setidaknya dua hal. Pertama, petani mengeringkan lahan (petakan) karena menghindari tanaman padi terserang oleh keong emas (Solikhin, 2004), karena keong emas memang merupakan hama yang serangannya bisa mengakibatkan kerusakan yang sangat berarti. Keong emas dan orong-orong memang memerlukan kondisi lahan (tanah) yang kontradiktif, yaitu keong emas memerlukan air tergenang untuk beraktivitas sedangkan orong-orong justru membutuhkan kondisi tanah tidak tergenang tapi basah (lembab). Kedua, adanya pergiliran air setiap empat hari sekali yang berarti selama empat hari air mengalir lalu air mati (tidak

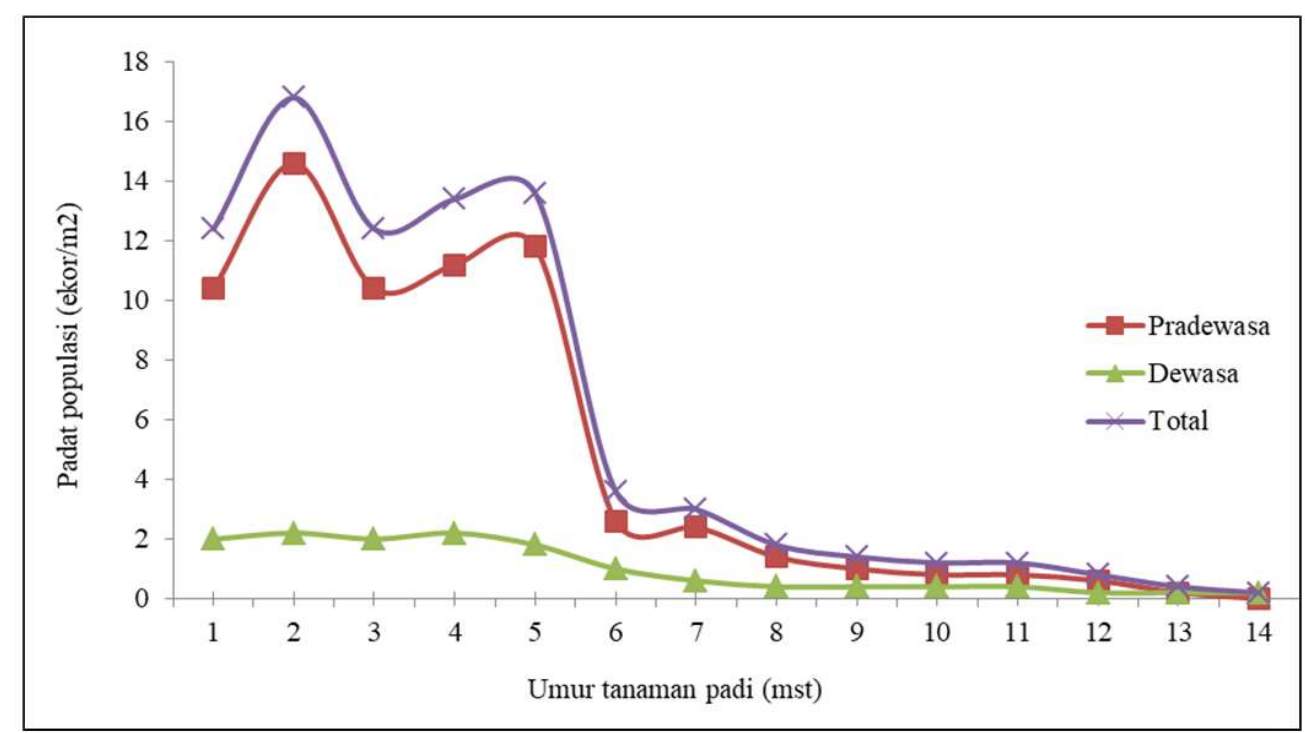

Gambar 1. Padat populasi orong-orong pradewasa,dewasa,dan total selama satu musim tanam gadu. 
mengalir) selama empat hari. Pengairan seperti ini dikenal dengan istilah inter mitten. Hal ini berakibat pada cocoknya orong-orong hidup dan berkembang biak. Mulai tahun 2015 ada pergiliran air berdasarkan kanal, artinya pada musim tanam gadu akan ada kanal (saluran air) yang benar-benar tidak dialiri air irigasi yang kemungkinan akan banyak mempengaruhi biologi hama-hama tanaman padi. Selama ini yang berlaku adalah pergiliran berdasarkan zona atas- bawah dengan pola tanam padi-padi-bera atau padi-padipalawija. Pada musim tanam gadu bagi yang mendapatkan jatah tanam diberlakukan empat hari air mengalir dandiikuti dengan empat hari tanpa air.

Setelah pertanaman padi memasuki umur $5 \mathrm{mst}$ populasi orong-orong mulai menurun drastis, hal ini kemungkinan karena orong-orong hanya bisa menyelamatkan diri (mengungsi) di pematang sedangkan kemampuan pematang untuk menopangkehidupan orong-orong kemungkinan terbatas. Sering ditemui orong-orong makan akar gulma dan merusak pematang dengan cara membuat lorong yang luar biasa banyaknya sehingga pematang tidak bisa dilewati karena menjadi sangat gembur (tidak kuat). Keberadaan orong-orong di pematang mungkin akan sangat terganggu jika petani melakukan aplikasi herbisida pada pematang tersebut.

Hubungan antara padat populasi orong-orong total (dewasa dan pradewasa) dengan intensitas serangan (kerusakan) selama satu musim tanam tersaji pada Gambar 2. Secara umum terlihat bahwa menigkatnya padat populasi orong-orong diikuti dengan meningkatnya intensitas serangan (kerusakan) pertanaman padioleh orong-orong tersebut. Memang pada saat padat populasi tertinggi ternyata tidak diikuti oleh tertingginya intensitas serangan (kerusakan), hal ini karena gejala kerusakan oleh orong-orong tidak serta merta terlihat setelah adanya seranagan orongorong, butuh waktu sekitar 3hari untuk terlihatnya gejala.

Gejala kerusakan oleh orong-orong berupa menguningnya daun yangkalau dilihat darikejauhan miripdengangejala kerusakan oleh tikus dan penggerek

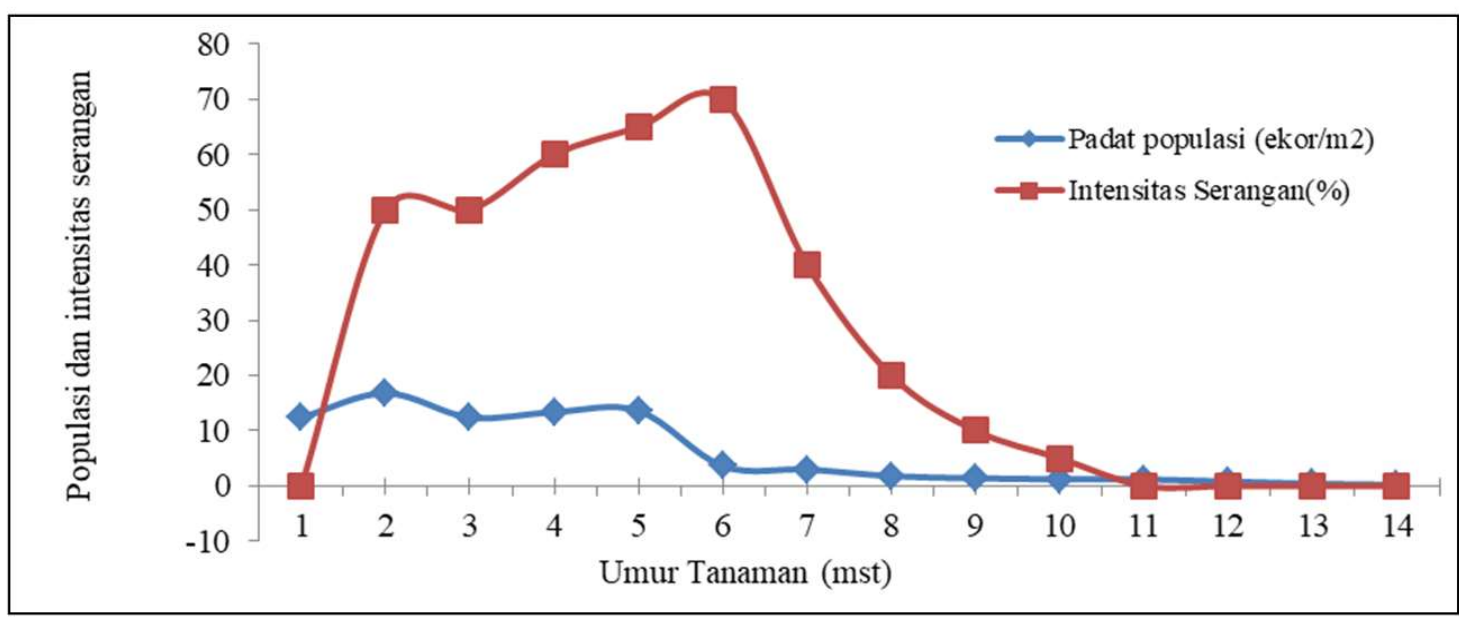

Gambar 2. Hubungan antara padat populasi orong-orong dengan intensitas serangan pada pertanaman padi selama musim tanam gadu. 
batang padi. Namun jika dilihat daridekat maka akan nyata terlihat bedanya, apalagi kalau dilihat perakarannya. Orong-orong menyerang tanaman padi dengan memakan (memotong) akar tanaman padi dan memakannya. Gejala ini akan terakumulasi sampai pengamatan terakhir, tetapi jika tidakberhati-hati maka pertanaman pada fase akhir seolah-olah tidak terserang orong-orong. Hal ini terjadi karena pada tanaman yang memasuki fase generatifanakan yangmasih tersisa akan tetap bertahan hidup dan mampu memulihkan perakarannya.

Hingga saat ini, upaya pengendalian hama orong-orong masih minim dilakukan. Orong-orong (Gryllotalpa spp.) menghabiskan hampir seluruh hidupnya di bawah permukaan tanah, oleh sebab itu pengendalian yang umum dilakukan adalah dengan menggunakan insektisida yang mempunyai sifat sistemik dan broad spectrum (Setiawati et al., 2015).

\section{KESIMPULAN}

Orong-orong (Gryllotalpa spp.) berada pada pematang sawah dengan kepadatan populasi naik sampai pertanaman berumur sekitar 35 hari setelah tanam kemudian menurun sampai menjelang panen. Orong-orong yang dtemukan berupa pradewasa dan dewasa, namun lebih banyak yang pradewasa. Padat populasi orong-orong menunjukkan hubungan linier berbanding lurus terhadap kerusakan tanaman padi yang diakibatkan oleh serangan orong-orong tersebut.

\section{DAFTAR PUSTAKA}

Antara Jatim. 2013. Puluhan Sawah di Kabupaten Madiun Terserang Hama. http://antara jatim.com/lihat/berita/110506/puluhan-sawahdi-kabupaten-madiun-terserang-hama. [18 Juni 2014].

Borror, D.J. \& R.E. White. 1970. A Field Guide to The Insect of America of Mexico. Houghton Mifflin Company, Boston.

Gallagher, K. 1991. Pengendalian Hama Terpadu untuk Padi: Suatu Pendekatan Ekologi. Proyek Prasarana Fisik BAPPENAS-1991.

Kalshoven, L.G.E. 1981. The Pests of Crops in Indonesia. Revised and translated by P.A. Van Der Laan; with the assistance of G.H.L. Rothschild. PT. Ichtiar Baru-Van Hoeve. Jakarta.

Lampung Post. 2014. Stok Beras Aman Sampai 2015. Edisi Selasa, 26Agustus 2014, halaman 9.

Oka, I.N. 1995. Pengendalian Hama Tepadu dan Implementasinya di Indonesia. Gadjah Mada University Press. Yogyakarta.

Setiawati, W, Jayanti, H, Hudayya, A, \& Hasyim, A. 2015. Pengaruh Insektisida Karbofuran Terhadap Kerusakan dan Kehilangan Hasil Kentang Akibat Serangan Gryllotalpa hirsuta Burmeister (Ortoptera : Gryllotalpidae) Serta Dampaknya Terhadap Keanekaragaman Artropoda Tanah. J. Hort. 25(1), pp. 54-62.

Singleton, G.R. \& D.A. Petch. 1994. A Review of the Biology and Management of Rodent Pests in Southeast Asia. Australian Centre for 
International Agricultural Research. Canberra. 65 pp.

Solikhin. 2004. Pengaruh Pola Permukaan (Profil) Petakan Sawah terhadap Serangan Keong Emas (Pomacea sp.) dan Orong-orong (Gryllotalpa sp.) pada Pertanamn Padi Fase Vegetatif Awal. Laporan Hasil Penelitian Kolborasi Program SEMI-QUE V, Jurusan Proteksi Tanaman Fakultas Pertanian Unila.
Sumodiningrat, G. 2001. Menuju Swasembada Pangan Revolusi Hijau II: Introduksi Manajemen dalam Pertanian. Penerbit RBI, Jakarta.

Vergara, B.S. 1990. Bercocok Tanam Padi. Diterjemahkan oleh M. Syam dkk. Proyek Prasarana Fisik BAPPENAS. 